Virginia: The Triumph of Experience Over Hope

John J. McGlennon

Each fall, the nation's newspapers' Sunday comic sections include a classic representation of unfailing optimism confronting harsh reality. Lucy Van Pelt, the crabby protagonist of "Peanuts" fame, once again offers the eternally hopeful Charlie Brown the opportunity to relish the thrill of placekicking a football into the crisp autumn air. Though he knows he's been cruelly tricked before, each year Charlie Brown finally succumbs to the possibility that this will finally be his year. As he races toward the ball, Lucy once again snatches it off the ground, leaving our hero flat on his back, ruing his gullibility.

Every four years, Virginia's Democrats approach the Presidential election with much the same script. With varying degrees of encouragement from presidential candidates and national party leaders, the only question confronting them seems to be how close they can get to the ball before it is snatched away. In 2004, the ball stayed on the ground longer than usual, but ultimately Virginia once again cast its electoral votes for the Republican ticket in the national election. President George W. Bush defeated Senator John F. Kerry by a margin of 53 to 45 percent, almost identical to the 2000 election results despite a significant expenditure of resources on behalf of Kerry.

\title{
The Political Environment
}

Political developments in the Old Dominion suggested only modest reasons to think that Virginia might be competitive in the 2004 Presidential contest. It had been 40 years since a Republican had lost Virginia in the national contest, matching the longest active string of wins by either party in any state. Virginia alone among the states of the Confederacy had failed to support Jimmy Carter's election in 1976, and the state had also resisted the appeal of the all-South ticket of Clinton-Gore in 1992 and 1996.

Since the late 1990s, Republicans had taken control of both houses of the General Assembly. Reapportionment of the Congressional and General Assembly seats was under the complete control of the GOP in 2001, with

JOHN J. MCGLENNON is professor of political science at the College of William and Mary.

The American Review of Politics, Vol. 26, Summer, 2005: 245-265

(C)2005 The American Review of Politics 
Table 1. Presidential Vote in Virginia by Party, 1900-2004

\begin{tabular}{|c|c|c|c|c|c|}
\hline \multirow[b]{2}{*}{ Year } & \multirow[b]{2}{*}{ National Winner } & \multirow[b]{2}{*}{ Virginia Winner } & \multicolumn{2}{|c|}{ Virginia Vote $(\%)$} & \multirow[b]{2}{*}{ Other } \\
\hline & & & Dem & Rep & \\
\hline 1900 & McKinley (R) & Bryan (D) & 55.3 & 43.8 & 0.9 \\
\hline 1904 & Roosevelt (R) & Parker (D) & 61.8 & 37.0 & 1.2 \\
\hline 1908 & Taft (R) & Bryan (D) & 60.5 & 38.4 & 1.3 \\
\hline 1912 & Wilson (D) & Wilson (D) & 66.0 & 17.0 & 17.0 \\
\hline 1916 & Wilson (D) & Wilson (D) & 67.0 & 31.8 & 1.2 \\
\hline 1920 & Harding (R) & Cox (D) & 61.3 & 37.9 & 0.8 \\
\hline 1924 & Coolidge (R) & Davis (D) & 62.5 & 32.8 & 4.7 \\
\hline 1928 & Hoover (R) & Hoover (R) & 45.9 & 53.9 & 0.2 \\
\hline 1932 & Roosevelt (D) & Roosevelt (D) & 68.5 & 30.1 & 1.4 \\
\hline 1936 & Roosevelt (D) & Roosevelt (D) & 70.2 & 29.4 & 0.4 \\
\hline 1940 & Roosevelt (D) & Roosevelt (D) & 68.1 & 31.6 & 0.3 \\
\hline 1944 & Roosevelt (D) & Roosevelt (D) & 62.4 & 37.4 & 0.2 \\
\hline 1948 & Truman (D) & Truman (D) & 47.9 & 41.0 & 11.1 \\
\hline 1952 & Eisenhower (R) & Eisenhower (R) & 43.4 & 56.3 & 0.3 \\
\hline 1956 & Eisenhower (R) & Eisenhower (R) & 38.4 & 55.4 & 6.2 \\
\hline 1960 & Kennedy (D) & Nixon $(R)$ & 47.0 & 52.4 & 0.6 \\
\hline 1964 & Johnson (D) & Johnson (D) & 53.5 & 46.2 & 0.3 \\
\hline 1968 & Nixon (R) & Nixon (R) & 32.5 & 43.4 & 24.1 \\
\hline 1972 & Nixon (R) & Nixon (R) & 30.1 & 67.8 & 2.1 \\
\hline 1976 & Carter (D) & Ford (R) & 48.0 & 49.3 & 2.7 \\
\hline 1980 & Reagan (R) & Reagan (R) & 40.3 & 53.0 & 6.7 \\
\hline 1984 & Reagan (R) & Reagan (R) & 37.1 & 62.3 & 0.6 \\
\hline 1988 & Bush (R) & Bush (R) & 39.2 & 59.7 & 1.1 \\
\hline 1992 & Clinton (D) & Bush (R) & 40.6 & 45.0 & 14.4 \\
\hline 1996 & Clinton (D) & Dole (R) & 45.1 & 47.1 & 7.8 \\
\hline 2000 & Bush (R) & Bush (R) & 44.4 & 52.5 & 3.1 \\
\hline 2004 & Bush (R) & Bush (R) & 45.5 & 53.7 & 0.8 \\
\hline
\end{tabular}

Governor (and Republican National Committee Chair) James Gilmore working with narrow Republican majorities. The 2001 House of Delegates elections produced an overwhelming advantage for the GOP, which took 64 of the 100 seats, a twelve-seat increase over pre-election numbers. Republicans also gained an increased majority of the U.S. House delegation (to a margin 
of 8-3). With Republican former Governor George Allen ousting incumbent U.S. Senator Charles Robb in 2000, and joining Republican Senator John Warner, Democrats lost their one remaining statewide office. The GOP seemed very well positioned to repeat its Presidential success (Whitley 2004a).

Still, there were glimmers of life among Democrats anxious to turn the Old Dominion's colors from red (representing the media's depiction of states which voted for Bush in 2000) to blue (the color for Gore states). Virginia voters elected a Democratic Governor, Mark Warner, in 2001, continuing a pattern where the party losing the presidency has claimed the Commonwealth's chief executive position the following year. Warner's victory demonstrated the ability of a Democrat to regain footing in the state's rural areas (Sabato 2001, 7).

Divisions within the state Republican Party over fiscal policy issues and personalities were evident, especially in the state legislature. Conservative, anti-tax Delegates newer to the legislature dominated the GOP caucus of the lower house, while more moderate Senate Republicans who had stalemated with Governor Gilmore over revisions to the state budget in 2001 continued to find themselves at odds. The budget impasse between Gilmore and the Senate contributed to Mark Warner's election (Clines 2001).

Finally, Virginia's demographics convinced some party strategists that the Old Dominion was underperforming relative to its Democratic vote potential. As will be discussed later, in the Democrats' search for new targets of opportunity, this perception did put Virginia for a time among the battleground states, at least for the Democrats (Whitley 2004b).

\section{Previous Presidential Results}

Virginia's preferences in presidential voting during the 20th century reflected nearly perfect symmetry. For the first half of the century, Democrats had carried the state in every presidential contest but one (when Republican Herbert Hoover beat Irish-Catholic, anti-Prohibition Democrat Al Smith in 1928). During the second half, Republicans prevailed every time except 1964, when Lyndon Johnson defeated Barry Goldwater. Republican margins varied from Richard Nixon's 37.7 percent win in 1972 to Gerald Ford's 1.3 percent edge over Jimmy Carter in 1976.

The most recent elections have shown a narrowing of the Republican advantage. While the average Republican vote in presidential elections from 1952 to 1988 was 54.6 percent (versus 40.9 percent for Democrats), the average of the last three elections gave Republicans an average advantage of only 48.2 to 43.4 percent for the Democrats. 
Table 2. Partisan Trends in Virginia Presidential Voting

\begin{tabular}{lccc}
\hline Years & Average Rep. \% & Average Dem. \% & Rep. Margin \\
\hline $1952-1968$ & 50.7 & 43.0 & +7.7 \\
$1972-1988$ & 58.4 & 38.9 & +19.5 \\
$1952-1988$ & 54.6 & 40.9 & +13.7 \\
$1992-2000$ & 48.2 & 43.4 & +4.8 \\
$1992-2004$ & 49.6 & 43.9 & +5.7 \\
Source: Compiled by author. & & \\
\hline
\end{tabular}

\section{Virginia in the Nominating Process}

For many years, voters in Virginia remained largely on the sidelines of presidential nominating politics. The state parties opted to use caucuses and conventions to pick their national convention delegations, and the timetable for selection often came after nomination contests were effectively determined. In 1988, as part of a regional effort to increase the influence of southern Democrats over the Presidential nomination, state legislatures in a number of states agreed on a common primary date in early March. This regional date, on which a substantial number of nominating convention delegates would be allocated, became known as Super Tuesday.

Low voter turnout characterized the Virginia primary more than a decisive impact on either party's presidential nomination, and primaries were dropped until the 2000 contest. In that year, Republicans who controlled the General Assembly and Governorship set February 29 as primary day. That selection meant that while Virginians could vote for their preferred Republican candidate for president, state Democrats could not use the primary method since it came one day before the window permitted by the Democratic National Committee for a primary by any state except New Hampshire. Democrats used caucuses once again, long after Vice President Al Gore had vanquished former Senator Bill Bradley (McGlennon 2001).

The contest for the presidential nomination in 2000 was more heated and significant for Republicans than for Democrats. Governor Gilmore actively supported fellow governor George W. Bush over his main challenger, Arizona Senator John McCain (Schapiro 2004). McCain and Bush both campaigned in Virginia, and McCain in particular drew national reporters and attention to the state. His effort, however, was aimed less at winning support in the Old Dominion than in staking out his independence from the Religious Right, as personified by Virginia-based religious broadcasters Pat 
Robertson and Jerry Falwell. In fact, though McCain traveled to Virginia Beach to criticize Robertson on his home turf, many speculated that the real audience he was speaking to were independent and Democratic voters who might vote in the open Michigan primary on the same day as Virginia's. Bush handily won in the Commonwealth while McCain scored impressively in Michigan.

\section{The 2004 Nomination Contest}

Changes in the Democratic nomination rules made it possible for Virginia Democrats to use a primary to allocate convention votes in 2004, and the state attracted early interest from a number of candidates. In the fall of 2003, several Presidential campaigns were in varying degrees of activity in Virginia. State Democratic Chairman Larry Framme took on leadership of the John Kerry campaign, and he was joined by a number of prominent party leaders and elected officials.

Howard Dean's grassroots effort, using internet communications to foster "meet ups," regular gatherings of people from the same area of Virginia who otherwise might not have known each other, showed the same fervor and rapid expansion as he was experiencing across the nation. Dean also counted among his supporters Donald Beyer, former lieutenant governor and 1997 gubernatorial nominee. Beyer served as national treasurer of the Dean campaign.

Another contender, Florida Senator Bob Graham, signed on political consultants with recent experience in Mark Warner's campaign, including Roanoke Democrat "Mudcat" Saunders, who convinced Graham to enter a racing pickup truck in NASCAR events. Saunders had encouraged Warner to have a stock car advertise his candidacy for Governor to considerable publicity, and he had written a country jingle which was used in Warner radio ads in rural areas of the state.

John Edwards found support from Democrats attracted by his southernaccented record, his effective speaking style, and his next-door-neighbor status as U.S. Senator from North Carolina. General Wesley Clark felt his military background and more conservative image would find support, especially in Hampton Roads, with its massive military installations and large number of retirees. Connecticut Senator and 2000 Vice Presidential nominee Joseph Lieberman snagged an early endorsement from Lt. Governor Timothy Kaine, the Democrats' presumptive 2005 gubernatorial candidate.

As was true in other states, Missouri Congressman Richard Gephardt drew his support mainly from organized labor, and Dennis Kucinich, Al Sharpton, and Carol Moseley Braun had only limited support in the early stages of the campaign. 
Table 3. 2004 Democratic Presidential Primary Polls in Virginia*

\begin{tabular}{|c|c|c|c|c|c|}
\hline Candidate & Dec. 2003 & Feb. 2004 & Feb. 2004 & Feb. 2004 & $\begin{array}{l}\text { Primary } \\
\text { Vote \% }\end{array}$ \\
\hline Dean & 21 & 8 & 9 & 10 & 7.0 \\
\hline Lieberman & 13 & $\mathrm{n} / \mathrm{a}$ & $\mathrm{n} / \mathrm{a}$ & $\mathrm{n} / \mathrm{a}$ & 0.7 \\
\hline Clark & 11 & 14 & 17 & 11 & 9.2 \\
\hline Gephardt & 8 & $\mathrm{n} / \mathrm{a}$ & $\mathrm{n} / \mathrm{a}$ & $\mathrm{n} / \mathrm{a}$ & 0.2 \\
\hline Kerry & 7 & 34 & 35 & 47 & 51.5 \\
\hline Sharpton & 6 & 5 & 1 & 3 & 3.3 \\
\hline Edwards & 5 & 25 & 22 & 24 & 26.6 \\
\hline Braun & 0 & $\mathrm{n} / \mathrm{a}$ & $\mathrm{n} / \mathrm{a}$ & $\mathrm{n} / \mathrm{a}$ & $\mathrm{n} / \mathrm{a}$ \\
\hline Kucinich & 1 & 1 & 1 & 2 & 1.3 \\
\hline Other/DK & 28 & 13 & 15 & 3 & 0.3 \\
\hline \multicolumn{6}{|c|}{$\begin{array}{l}\text { *The first four columns of data represent poll results as follows: Mason-Dixon Poll, December 3-5, } \\
\text { 2003; Mason-Dixon Poll, February 4-5, 2004; American Research Group poll, February 4-6, 2004; } \\
\text { Zogby International Poll, February 7-8, 2004. The last column represents the percentage of the vote } \\
\text { each candidate received in the Virginia primary held on February 10, } 2004 \text { (State Board of Elec- } \\
\text { tions). }\end{array}$} \\
\hline
\end{tabular}

Table 4. Virginia Democratic Primary Results, February 10, 2004

\begin{tabular}{lrc}
\hline Candidate & Total Vote & Percentage \\
\hline John Kerry & 204,142 & 51.5 \\
John Edwards & 105,504 & 26.6 \\
Wesley Clark & 36,572 & 9.2 \\
Howard Dean & 27,637 & 7.0 \\
Al Sharpton & 12,864 & 3.3 \\
Dennis Kucinich & 5,016 & 1.3 \\
Joe Lieberman & 2,866 & 0.7 \\
Lyndon LaRouche & 1,042 & 0.3 \\
Dick Gephardt & 580 & 0.2
\end{tabular}

Source: State Board of Elections, Commonwealth of Virginia, Official Res ults, February 10, 2004 Primary (accessed at http://sbe.vipnet.org/feb2004/d_01.htm). 
Initial polling in Virginia indicated results similar to other states across the nation. A December survey found Governor Dean in a substantial lead over Senator Lieberman and General Clark with other candidates lagging behind. But as active campaigning got under way, the order of candidates quickly reshuffled. Dean's rapid downfall in Iowa was reflected in new polling in Virginia in February, as John Kerry, with wins in Iowa and New Hampshire and the growing support of party and elected leaders, began to surge. With Braun, Graham, Gephardt, and Lieberman all out of the race, the February 10 primary shaped up as a test of whether Clark or Edwards could upset Kerry's momentum.

Kerry invested in television advertising in the Commonwealth, and both Clark and Edwards put substantial money into the state (Whitley 2004C). The competition to emerge as Kerry's competitor seemed to frustrate both, however, and Kerry received a substantial boost with Governor Warner's endorsement in the days leading up to voting (Eisman 2004).

On Primary Day, a majority of the 396,223 voters selected Kerry, besting John Edwards by a nearly 2-1 margin, 51.7 to 26.6 percent. General Clark, who had consistently polled in double digits, finished with only 9.3 percent. Total turnout was just 9.3 percent of registered voters, falling far short of the 664,000 GOP primary voters in 2000 (State Board of Elections 2005a).

Kerry's support was strong across the state, as he won between 46.7 and 55.7 percent of the vote in sweeping the eleven congressional districts of the state. Edwards exceeded 30 percent in only two southwestern Virginia districts, as he came within nine percent of Kerry's vote in the fabled "Fighting Ninth" District.

The relatively open competition for the Democratic nomination, coupled with the early voting date, brought Virginia unusual attention in 2004, with candidate campaign appearances, active organizations, and television and radio ads. While the turnout was less than overwhelming, the Commonwealth's voters took another step, after the heated Republican contest of 2000, to making Virginia an active player in nomination politics.

In both 2000 and 2004, Virginia's governors provided a critical endorsement to the winning candidate. Demonstrating a willingness to risk their prestige in what previous governors had seen as an enterprise carrying little benefit, Gilmore and Warner both delivered for their preferred candidates and raised their national stature as a result.

Though the nomination contest for the Democrats continued for a few more weeks, the Virginia primary, along with the vote in Tennessee on the same day, substantially weakened the challenge to Kerry's nomination. John Edwards would mount one last effort in Ohio on March 7, but with only a 
victory in his native South Carolina to his credit, his claim of greater electability was unsustainable. General Clark withdrew and endorsed Kerry after the disappointing results in the two neighboring states (Schapiro 2004).

\section{The General Election: Endless Summer}

Both Democrats and Republicans approached the early months of the 2004 election with visions of 1996 on their minds. In that year, with President Bill Clinton uncontested for re-nomination, the Democrats prepared a well-funded and effective campaign to undermine the eventual GOP nominee as soon as he emerged from a bloody, resource-depleting primary season. Kansas Senator Robert Dole withstood a furious challenge and wrapped up his party's nod by late March. In the process, he had raised and spent the maximum amounts of money permitted under the voluntary federal matching funds program. His campaign, virtually broke for the nearly four months until the Republican National Convention, could only stand by as Clinton unleashed his primary dollars and unregulated "soft dollars" to attack Dole's record (Polsby 2004, 57).

In 2004, Republicans appeared poised to launch a similar barrage of negative ads against the eventual Democratic nominee. With campaign finance laws now restricting soft money, the Bush campaign had opted out of the pre-nomination matching funds program. This freed the campaign to raise and spend amounts unlimited in total and without limits in individual states. Anticipating a lengthy and expensive Democratic race, Bush's team planned to overwhelm the Democrats in April, May, and June, with record setting funds raised for the nomination.

The Democrats understood the potential dilemma, and both the Democratic National Committee and the leading candidates took steps to address it. National Chairman Terry McAulliffe had convinced the party to "frontload" the nomination calendar in hopes of effectively settling on a nominee by mid-March. The party also began stockpiling money for "party" ads to respond to the GOP assault. The DNC would not be able to match the Bush expenditures, but they would try to avoid being drowned out.

Early on, the leading Democratic candidates had their own plans to respond to the Republican strategy. Howard Dean caught the attention of the nation's political establishment when he announced that, like Bush, he would opt out of the public finance system for the nomination, and he posted eye-popping amounts of contributions. The decision and the money became part of Dean's campaign rationale, as he stated that only he would be in the financial position to compete with Bush through the spring and summer. Dean's money, largely raised over the internet from Democratic activists attracted by his forceful defense of the Democratic agenda and equally forceful opposition to President Bush's invasion of Iraq, forced a response. 
Recognizing that Dean was generating both a sizable cash advantage and a powerful argument for nomination, Kerry also opted out of matching funds, which would also allow him to use personal funds (as he did in December when his campaign was losing support, loaning it \$7 million dollars). In the end, Dean, Kerry, and Bush all shattered previous fundraising totals. Kerry and Bush each raised well over \$200 million, the bulk of which was spent long after the nomination contest had ended but before the nominating conventions. This enormous pool of money opened up new possibilities for presidential campaigns which in earlier years were strictly constrained by spending limits.

Polling and conventional wisdom suggested a largely unchanged playing field from the disputed 2000 election, with about three-quarters of the states being assigned to "red" or "blue" categories and predicted to remain with their previous choice of party in the 2004 election. Another group of states were expected to be closely contested due to narrow margins in 2000, led by Florida, Ohio, Iowa, Minnesota, and New Mexico. Both campaigns looked for "targets of opportunity," states which had supported the other party in 2000 but which might be successfully contested in 2004 .

For the Bush campaign, New Jersey represented such a potential gamble. Though it had supported Gore by double digits, polling suggested that the state's voters were highly sensitized to security issues due to their proximity to the site of the World Trade Center attacks.

Democrats' attempts to expand the playing field included forays into West Virginia, Arizona, Colorado, North Carolina, and Virginia, among others. Virginia was an appealing target for several reasons: its relatively close ( 8 percent) margin in 2000 despite no investment by Gore's campaign; its demographics suggested higher Democratic potential; Kerry's military record, which might appeal to a larger veteran population; and Warner's success in 2001 (Mercer 2004; Edds 2004).

After decades of losing presidential contests, Virginia Democrats came close to carrying the state in both 1992 and 1996. With little more than a last minute foray across the Potomac River from Washington into Northern Virginia, Clinton had come within 2 percentage points of defeating Senator Dole. Gore's single-digit loss with no effort convinced Democrats in Virginia the state was worth targeting.

The underlying characteristics of the state's population raised questions about whether Democrats had significant additional potential in the Old Dominion. With college graduates generally showing increased support for the Democratic presidential nominee, Virginia's rank as having the 4th highest proportion of college graduates was significant (U.S. Census Bureau). Unmarried voters were substantially more likely to favor Democrats, and again, Virginia's population was disproportionately single. 
Throughout the spring and summer, Kerry strategists pointed to anecdotal suggestions of dissatisfaction within the military with the Bush Administration in general and Secretary of Defense Donald Rumsfeld in particular. Democrats argued that Kerry, as a decorated veteran of the War in Vietnam, would have unusual appeal to normally Republican active and retired military personnel.

Kerry signaled his own interest in contesting the Commonwealth when he chose to attend the historic Memorial Day parade in the Navy city of Portsmouth. He followed that with a swing through Norfolk on his way to the Democratic National Convention in July (Geroux 2004). Republicans professed little concern over Kerry's activities, which they characterized as misdirection aimed at getting them to waste resources in "safe" Virginia. But the Democrats' decision to purchase $\$ 750,000$ in television ads across much of the state over the summer gave some credibility to the Democrats' contentions (Whitley 2004d; Edds 2004).

Public opinion polls gave plausibility to Kerry's investment as they continued to show President Bush unable to establish a solid lead in the historically Republican state. With the financial resources to compete, the Democrats began to ramp up the staffing for Kerry. Governor Warner's election offered not only a strategy for winning, but a solid organizational base to work from. Warner had devoted a healthy share of his $\$ 20$ million campaign budget to building a data base of Virginia voters which was ready for Kerry's use.

In addition to his gubernatorial success, Warner received prominent mention as a possible vice-presidential running mate for Kerry. He was a highly visible presence in Boston at the Democratic National Convention as well (Fiske 2004a) The voters of Virginia began to sense that their votes might actually matter in the presidential election.

\section{The Double Edge of Vietnam}

Whatever benefit John Kerry hoped to draw from his Vietnam experience, it was clear that his protests of the war would generate as much attention as his military conduct. But it was surprising to find that his record in Vietnam also came under attack. Kerry had been dogged throughout his career by charges of disloyalty for taking on a leadership role in Vietnam Veterans Against the War. In that capacity, Kerry gave speeches and testified before televised congressional hearings, establishing him as a prominent political figure. Over the years, he was criticized by some veterans and defenders of the Vietnam policy, but in 2004 a new front of attack on Kerry was opened. 
Table 5. Virginia Presidential Election Polls, General Election

\begin{tabular}{llcccc}
\hline Date & Survey & Bush & Kerry & DK/Other & Margin \\
\hline May & Rasmussen & 47 & 45 & 8 & 2 \\
June & Rasmussen & 48 & 45 & 7 & 3 \\
July 6-7 & SurveyUSA & 50 & 45 & 5 & 5 \\
July & Rasmussen & 49 & 46 & 5 & 3 \\
Aug 20-22 & SurveyUSA & 49 & 45 & 6 & 4 \\
August & Rasmussen & 50 & 45 & 5 & 5 \\
Sept 12-14 & ARG & 49 & 43 & 8 & 6 \\
Sept 21-23 & SurveyUSA & 53 & 42 & 5 & 11 \\
Sept 24-27 & Mason-Dixon & 49 & 43 & 8 & 6 \\
Sept 14-27 & Rasmussen & 50 & 44 & 6 & 6 \\
Oct 16-18 & SurveyUSA & 50 & 46 & 4 & 4 \\
Oct 22-25 & Mason-Dixon & 50 & 44 & 6 & 6 \\
Oct 20-26 & Times-Dispatch & 49 & 40 & 11 & 9 \\
Oct 27-29 & SurveyUSA & 51 & 47 & 2 & 4
\end{tabular}

Source: Virginia 2004 Polls, Real Clear Politics (accessed at http://www.realclearpolitics.com/ Presidential_04/va_polls.htm).

A group of Vietnam-era veterans, led by John O'Neill who had debated Kerry on the war since Kerry emerged on the national stage, argued that Kerry's record in Vietnam, which had won him three Purple Hearts, was questionable. This group, using statements from others who had served on similar duty to Kerry, though not on the same boat and not at the same time in most cases, raised questions about the extent of Kerry's injuries, whether he was really taking heroic action in the events which won him medals, and whether his recollection of his service was true.

Organized as a so-called "527 Group" under the name "Swift Boat Veterans for Truth" after the vessel type that Kerry commanded, these antiKerry Vietnam veterans worked with a Texas Republican donor to put together a television commercial which they aired with a modest buy on cable television in a handful of states. The commercials themselves got far less exposure initially than the leaders of the group attained with press conferences, news coverage of their ads, and appearances on the many political talk shows which had sprung up on cable and broadcast television (Edsall and Grimaldi 2004).

This publicity fueled an ongoing debate with the Kerry campaign and ultimately became a major force in the election campaign. The 527 group was able to run advertisements in which they did not directly call for Kerry's defeat, and they benefited from their legal status by not having to disclose donors nor adhere to contribution limits. Their success with limited 
resources attracted the attention of Bush supporters, who encouraged them to expand their efforts. Ultimately SBVT spent more than \$28 million on their efforts to influence the election outcome (Edsall and Grimaldi 2004).

Prominent in the Swift Boat organization were a number of Virginians: Navy Admiral Roy Hoffman (ret.) of Virginia's Chesterfield County outside of Richmond; Paul and Phyllis Galanti, a Vietnam-era POW and his wife (who, along with Admiral Hoffman appeared in ads for the group); and Chris LaCivita, a well-known political consultant who had been involved in Virginia Republican campaigns for many years (Hoffman 2004; Whitley 2004e).

Increasingly, news coverage in Virginia focused on the intense opposition to Kerry's candidacy among veterans (Lewis 2004). While no real change was evident in statewide polling, the Kerry campaign nationally was spending much of August and September on the defensive, forced to shore up support in "blue" states. By early September, Kerry had dropped plans to advertise in the Commonwealth (Fiske 2004b; Whitley 2004f). By early October, Kerry's Virginia campaign was closing shop, with paid staffers being reassigned to more competitive states (Sluss 2004).

Despite the shift of the national campaign, election activity remained high in Virginia, fueled by volunteers for both parties (Dellinger 2004). Voters were able to follow campaign events and advertisements on cable television and the internet (Stallsmith 2004). After years of being largely untouched by presidential campaigning, Virginians had a steady diet of ads for and against President Bush on national cable channels as well as a hefty dose of attacks on Kerry.

\section{The Election: Turnout}

With the professional campaigns having abandoned Virginia, with no analysts predicting an upset in the state, with no U.S. Senate race, and with only three even modestly competitive races for the U.S. House of Representatives, it would have been reasonable to expect an anemic level of voter turnout on November 2. Instead, participation surged by 16.8 percent, rising to just under 3.2 million votes cast (State Board of Elections 2005b).

Almost all cities and counties showed significant increases, taking into account variations in growth rate. Even some communities showing population losses experienced increases in total vote over the 2000 level. Norfolk, a city that had lost ten percent of its population in the previous decade, saw its turnout jump by 13 percent.

The Virginia turnout increase matched the national increase and approached the turnout increase in Ohio, where an estimated \$100 million dollars of expenditure raised the vote by 19 percent. Although the state had 
Table 6. Change in Virginia Presidential Vote Turnout, 1988-2004

\begin{tabular}{cccc}
\hline Year & Turnout & Increase in Vote & Percent Increase \\
\hline 1988 & $2,191,604$ & 44,974 & 2.1 \\
1992 & $2,558,665$ & 367,056 & 16.7 \\
1996 & $2,416,642$ & $(-241,642)$ & $(-9.4)$ \\
2000 & $2,739,447$ & 322,805 & 13.4 \\
2004 & $3,198,367$ & 458,920 & 16.8 \\
\multicolumn{2}{l}{ Source: State Board of Elections, Commonwealth of Virginia. } \\
\hline
\end{tabular}

experienced increases nearly as large in 1992 and 2000, both of those elections had been preceded by low turnout contests, making the increases seem larger. With the 2000 election having generated a double-digit increase, the 2004 surge was more remarkable.

Efforts to register and mobilize voters in the Old Dominion combined with reports of intense interest among the electorate. The results were double digit increases in many areas, from declining rural counties and central cities to fast growing suburbs. Ultimately the increasing central city and rural increases seemed to cancel each other out, and a larger share of the state vote continued to come from the fast growing suburbs of Northern Virginia, Hampton Roads, and Richmond.

\section{The Results}

In an election filled with remarkable moments, perhaps the most remarkable outcome was how little the partisan divide shifted. Despite the tragic and historic events of the preceding years, including September 11, the wars in Afghanistan and Iraq, economic recession, record-breaking campaign spending, unprecedented grassroots organization, and the resurrection of door-to-door canvassing, the overall landscape of presidential politics changed hardly at all between 2000 and 2004.

In Virginia, the vote for George Bush inched up from 52.47 to 53.68 percent, an increase of 1.21 percent. Al Gore's 44.44 percent was bested by John Kerry's 45.48 percent, an increase of 1.04 percent. The combined increase for the two major candidates almost precisely equaled the 2.17 percent earned by Ralph Nader in 2000. Nader failed to qualify for the Virginia ballot in 2004.

Despite predictions that the Democrats would finally break through in the Old Dominion or that George Bush would walk away with the state, in the end the Bush margin increased from 8.03 to 8.20 percent. A total of 10 
localities changed from one party to the other, though some were notable switches.

Suffolk, a fast-growing suburban city in military-heavy Hampton Roads, gave President Bush the edge, along with rural Southampton, Russell, and Caroline counties. Albemarle County, surrounding the University of Virginia's Charlottesville, and Williamsburg, home to the College of William \& Mary, shifted to the Democrats, reflecting their strong support in university communities. Fairfax County, home to one in seven Virginians and the largest jurisdiction in the state, went for a Democratic presidential candidate for the first time since 1964, along with the city of Danville and Prince Edward and Nelson counties.

Only 22 of the 134 cities and counties saw a change of five percent or more in the vote for the major party candidates. For Bush, these localities tended to be smaller communities located in the western and southwestern sections of the state. He did also show a slight increase in strength in the cities of Hampton Roads, again suggesting that Kerry's early emphasis on his military experience and his campaigning and advertising in the area had not helped him.

Kerry improved on Gore's performance mostly in cities (e.g., Richmond) and university towns. In addition to Williamsburg and Charlottesville, Kerry gained in Lexington, home of Washington \& Lee University and the Virginia Military Institute. His performance generally improved over Gore throughout Northern Virginia, especially in Falls Church, Arlington County, and the city of Alexandria.

\section{Components of the Vote}

If nationally President Bush built his victory on support from white, male Protestants, these groups provided even stronger backing in Virginia. According to National Election Pool exit polling, Bush's nine-point national margin over Kerry doubled in the state. White men (a third of the sample both nationally and in the Commonwealth) preferred Bush by 23 points across the country as a whole, but by twice that margin in the state.

Race was a far more powerful predictor of vote in Virginia than nationally. Female voters who were white gave Bush a narrow margin nationally, but in Virginia his edge in this group was three times as large.

Kerry benefited from overwhelming support among African Americans of both genders, still only enabling him to earn an even split with Bush among women in Virginia, even though he won among women nationally by 5 percent. With African-Americans constituting 21 percent of Virginia voters, they nearly doubled the national proportion (though Hispanics and Asians did not register a large enough number to be analyzed in the state). 
Virginia: The Triumph of Experience Over Hope | 259

Table 7. Vote for President by Group, National and Virginia Exit Polls

\begin{tabular}{|c|c|c|c|c|c|c|}
\hline \multirow{2}{*}{$\begin{array}{l}\text { Demographic } \\
\text { Characteristic }\end{array}$} & \multicolumn{3}{|c|}{-National- } & \multicolumn{3}{|c|}{$\longrightarrow$ Virginia -} \\
\hline & $\%$ of total & Bush & Kerry & $\%$ of Total & Bush & Kerry \\
\hline \multicolumn{7}{|l|}{ Gender } \\
\hline Male & 46 & 54 & 45 & 46 & 59 & 40 \\
\hline Female & 54 & 47 & 52 & 54 & 50 & 50 \\
\hline \multicolumn{7}{|l|}{ Gender by race } \\
\hline White male & 36 & 61 & 38 & 34 & 72 & 27 \\
\hline White female & 41 & 54 & 45 & 38 & 64 & 35 \\
\hline Non-white male & 10 & 30 & 68 & 12 & 25 & 73 \\
\hline Non-white female & 13 & 24 & 75 & 16 & 14 & 86 \\
\hline \multicolumn{7}{|l|}{ Race } \\
\hline White & 77 & 57 & 42 & 72 & 68 & 32 \\
\hline Black & 11 & 11 & 89 & 21 & 12 & 87 \\
\hline \multicolumn{7}{|l|}{ Age } \\
\hline $18-29$ & 17 & 44 & 54 & 17 & 46 & 54 \\
\hline $30-44$ & 28 & 51 & 47 & 32 & 59 & 40 \\
\hline $45-59$ & 30 & 50 & 49 & 32 & 52 & 47 \\
\hline $60+$ & 25 & 53 & 46 & 19 & 56 & 44 \\
\hline $18-64$ & 83 & 50 & 49 & 90 & 54 & 45 \\
\hline $65+$ & 17 & 51 & 48 & 10 & 49 & 51 \\
\hline \multicolumn{7}{|l|}{ Income } \\
\hline Less than $\$ 50,000$ & 45 & 43 & 56 & 39 & 48 & 52 \\
\hline$\$ 50,000$ or more & 55 & 55 & 44 & 61 & 57 & 43 \\
\hline \multicolumn{7}{|l|}{ Religion } \\
\hline Protestant & 53 & 58 & 41 & 68 & 57 & 43 \\
\hline Catholic & 27 & 51 & 48 & 15 & 63 & 36 \\
\hline Jewish & 3 & 24 & 76 & 2 & - & - \\
\hline Something else & 7 & 23 & 74 & 7 & 21 & 78 \\
\hline None & 10 & 30 & 68 & 8 & 37 & 63 \\
\hline \multicolumn{7}{|l|}{ White Protestant } \\
\hline Conservative & - & - & - & 22 & 95 & 5 \\
\hline \multicolumn{7}{|l|}{ Veteran Status } \\
\hline Veteran & 18 & 57 & 42 & 19 & 63 & 36 \\
\hline Non-veteran & 82 & 48 & 51 & 81 & 52 & 48 \\
\hline
\end{tabular}


Support for the two candidates varied by age, but here Virginia followed the national trend. As he did in the national poll, Kerry won among Virginia's youngest voters, and he also won by a narrow margin among those over 65 . Fortunately for Bush, the electorate included more voters in between, and they preferred to re-elect the incumbent. The age composition was even more favorable to Bush in Virginia. Economic differences were evident. Though he won among Virginians earning less than $\$ 50,000$ per year, the Massachusetts Senator's margin was far smaller in the state than nationally. Again, Virginia's electorate was comprised more heavily of the wealthier voters.

The predominantly Protestant Virginia electorate reflected the impact of religion. While Protestants supported Bush with 57 percent, white Protestants (half of all voters) gave him 72 percent, and white Protestant conservatives were nearly unanimous in supporting the incumbent. Virginia Catholics demonstrated a much higher level of support for Bush than he attained nationally, though they were a smaller component of the state's vote. Kerry had a decided advantage among the non-Christian electorate, consistent with his national performance.

The question of Kerry's appeal to veterans was a frequent topic leading up to the election. Exit polls (and national pre-elections surveys) supported GOP expectations. Veterans in the Old Dominion were 11 percent more likely than non-vets to back Bush. Of course, some of that difference could be accounted for by the fact that veterans were more likely to be male than female, but it turns out that among white men, veterans were much more strongly pro-Bush.

Table 8. Virginia Veterans' Vote by Race, Gender

\begin{tabular}{lccc}
\hline & Bush & Kerry & Difference \\
\hline All Veterans & 63 & 36 & +27 Bush \\
Male Veterans & 67 & 32 & +35 Bush \\
Female Veterans & 41 & 59 & +18 Kerry \\
White Veterans & 82 & 18 & +64 Bush \\
Black Veterans & 12 & 87 & +75 Kerry \\
White Male Veterans & 84 & 16 & +68 Bush \\
White Female Veterans & 71 & 29 & +42 Bush \\
Black Male Veterans & 11 & 87 & +76 Kerry \\
Black Female Veterans & 13 & 87 & +74 Kerry \\
Source: National Election Pool Exit Polls for Virginia, accessed at Inter-University Consortium for \\
Political and Social Research, University of Michigan and analyzed by author. \\
\hline
\end{tabular}


Taking into account the gender and racial differences in veteran status, the Bush advantage becomes clearer. Among males who were veterans (approximately 85 percent of Virginia's vets), Bush enjoyed a 34 percent edge, versus 8 percent among non-veteran males. Though women veterans actually supported Kerry by a 3-2 margin, their numbers were quite small, and non-veteran women split evenly between the candidates.

White veteran support for Bush was almost 20 percent higher than among whites who had not served in the military. Among African Americans, veteran status increased Bush's vote by less than two percent to 12 percent.

Virginia's electorate in 2004 was more Republican and more conservative than the nation at large by a modest proportion. With each candidate enjoying overwhelming support among their fellow partisans (a bit more for Bush than Kerry), that gave the President an advantage. He also scored well with independents, besting the Democrat by 10 percent. Liberals and conservatives similarly delivered lopsided support to Kerry and Bush respectively, but since there were twice as many voters on the right side of the political spectrum, Bush was able to withstand a 15 percent loss among the most numerous moderate voters.

Virginians gave higher approval to President Bush and the war in Iraq than did the national sample, but included a large minority of detractors as well. Again, attitudes on these two issues corresponded strongly to support for Bush or Kerry.

Candidate choice by Virginia voters corresponded closely to their identification of the most important issue in determining who to support. Those who identified terrorism, moral values, or taxes as their most important issue overwhelmingly preferred Bush, while Kerry won lopsided support among those citing Iraq, the economy, and health care.

Like the national electorate, Virginians worried about terrorism and, in a rare instance of broader consensus, a significant majority trusted Bush but not Kerry to address this concern.

In the same way that the most important issues corresponded to candidate choice, the most desired candidate traits reflected strong consensus on the appeals of the contenders. The single most often named trait sought by voters was the promise to "bring change," hardly a characteristic that an incumbent can offer in most circumstances, but almost a "fill in the blank" trait for a challenger. Though Kerry's main claim to offering change was that he was not Bush, 23 percent of Virginians thought this was an important trait, and they backed Kerry, 94 to 6 percent. Intelligence was named by 8 percent of voters, and they saw Kerry as having that trait, voting for him by a 95 to 5 margin. 
Table 9. Attitudes of Virginia Voters and Candidate Choice

\begin{tabular}{|c|c|c|c|c|}
\hline & $\begin{array}{l}\text { Percent } \\
\text { of Total }\end{array}$ & Bush & Kerry & Difference \\
\hline \multicolumn{5}{|l|}{ Party ID } \\
\hline Republican & 39 & 95 & 5 & +90 Bush \\
\hline Democratic & 35 & 8 & 92 & +84 Kerry \\
\hline Independent/Other & 26 & 54 & 44 & +10 Bush \\
\hline \multicolumn{5}{|l|}{ Ideology } \\
\hline Conservative & 38 & 85 & 15 & +70 Bush \\
\hline Moderate & 45 & 42 & 57 & +15 Kerry \\
\hline Liberal & 17 & 17 & 83 & +66 Kerry \\
\hline \multicolumn{5}{|c|}{ Approval of Bush as President } \\
\hline Approve & 55 & 92 & 8 & +84 Bush \\
\hline Disapprove & 44 & 6 & 93 & +87 Kerry \\
\hline \multicolumn{5}{|c|}{ Decision to go to war in Iraq } \\
\hline Approve & 51 & 86 & 13 & +73 Bush \\
\hline Disapprove & 43 & 14 & 85 & +71 Kerry \\
\hline \multicolumn{5}{|c|}{ Most important issue in election } \\
\hline Terrorism & 22 & 88 & 12 & +76 Bush \\
\hline Moral values & 22 & 87 & 13 & +74 Bush \\
\hline Iraq & 17 & 17 & 83 & +66 Kerry \\
\hline Economy/Jobs & 17 & 20 & 79 & +59 Kerry \\
\hline Health care & 6 & 15 & 85 & +70 Kerry \\
\hline Taxes & 5 & 79 & 21 & +58 Bush \\
\hline \multicolumn{5}{|c|}{ Most important candidate trait } \\
\hline Will bring change & 23 & 6 & 94 & +88 Kerry \\
\hline Is strong leader & 18 & 87 & 13 & +74 Bush \\
\hline Has clear stands & 16 & 81 & 18 & +63 Bush \\
\hline Strong religion & 11 & 97 & 2 & +95 Bush \\
\hline Honest, trustworthy & 11 & 76 & 24 & +52 Bush \\
\hline Cares about me & 8 & 33 & 67 & +34 Kerry \\
\hline Intelligent & 8 & 5 & 95 & +90 Kerry \\
\hline \multicolumn{5}{|c|}{ Who do you trust on terrorism? } \\
\hline Only Bush & 50 & 97 & 2 & +95 Bush \\
\hline Only Kerry & 26 & 2 & 98 & +96 Kerry \\
\hline Both & 12 & 28 & 72 & +44 Kerry \\
\hline Neither & 9 & 23 & 75 & +52 Kerry \\
\hline
\end{tabular}

Source: National Election Pool Exit Polls, accessed from Cable News Network (http://www.cnn. com/ELECTION/2004/pages/results/states/VA/P/00/epolls.0.html). 
"Religious faith" was an important trait to just more than one out of ten voters, and 97 percent of them named Bush as their candidate. Bush also won easily among voters who wanted "a strong leader," or "a clear stand on issues," and "honesty and integrity." Kerry won decisively among voters wanting a candidate who "cares about people like me."

Ultimately, the election in Virginia was about George Bush. Voters made up their minds early, and among those who said they were "voting for your candidate," Bush was the strong preference. For those voters motivated to vote "against his opponent" Kerry was the obvious beneficiary.

When the polls had closed, the votes were counted, and Virginia's electoral votes were assigned, once again the Republican nominee was the victor. But even on election day, the optimism of Charlie Brown was cruelly (and not for the first time) revived among Virginia's Democrats. Early (and, as it turned out, flawed) exit polling data which had been leaked out from the news media suggested, as they had on election day 2000, that Virginia was "too close to call" and that the Democrat had an edge. Just as visions of a national sweep danced in their heads, they figuratively landed on their backs only to see that the football had once again been pulled away.

\section{Postscript}

The political parties of the Old Dominion do not have the luxury of thoughtful analysis of the presidential election. In the year following the national vote, Virginia elects a new governor, thanks to a one-term-and-out limit on executive service. Even before the presidential contest ends, attention shifts to the race for the Executive Mansion. Republicans relished their tenth straight presidential win in the state, confident that Virginia is in their grasp. Democrats took solace in a tradition (extending back to 1977) that every gubernatorial winner in the Old Dominion in recent history came from the party losing the national contest for president.

With a furious contest already under way even before the end of 2004 (the frontrunner for each party had already raised in excess of $\$ 5$ million) and with the Democratic National Committee pledging an additional \$5 million to aid the Virginia campaign, the state could expect to be in the political spotlight once more.

Presidential politics also became more relevant to Virginians as Senator George Allen, fresh from his successful chairmanship of the National Republican Senatorial Committee, began to show interest in his party's open contest for the White House nomination in 2008. Not to be outdone, Democratic Governor Mark Warner, chairman of the National Governor's Association in 2005, gained prominent mention as the kind of potential nominee who had demonstrated the ability to turn a red state blue. Some even 
suggested that Allen and Warner would put their national ambitions to an early test in a face-off for Allen's Senate seat in 2006.

Once again, Virginia voted Republican in 2004, but the votes had barely been certified before it again began to promote discussion of what might be. The centrist Democratic Leadership Council in its analysis of the 2004 contest offered a roadmap for a Democratic comeback in 2008. It suggested a targeted appeal focused on states that had shown Democratic potential by holding President Bush's margin below ten percent: the list included three southern states, Florida, Arkansas, "and, surprisingly, Virginia" (Marshall 2004).

Tee up the pigskin, Charlie Brown!

\section{REFERENCES}

Clines, Francis X. 2001. G.O.P. Chairman Under Republican Fire Back Home. New York Times, March 23.

Dellinger, Paul. 2004. Bush, Kerry Offices, Signs Sprouting Up Across NRV. Roanoke Times \& World News, September 9.

Edds, Margaret. 2004. Why Kerry is Courting Virginia. Hampton Roads The VirginianPilot, June 6.

Edsall, Thomas, and James Grimaldi. 2004. On Nov. 2, GOP Got More Bang For Its Billions, Analysis Shows. Washington Post, December 30.

Eisman, Dale. 2004. VA's Turn Comes Today / Kerry Set on Victory, But Clark, Edwards Could Spring Upset. Hampton Roads The Virginian-Pilot, February 10.

Fiske, Warren. 2004a. Warner Promises Kerry Victory in Virginia. Hampton Roads The Virginian-Pilot, July 30.

Fiske, Warren. 2004b. Kerry Edges Away From “Air Battle” in Virginia. Hampton Roads The Virginian-Pilot, September 10.

Geroux, Bill. 2004. Kerry Arrives in Norfolk; Navy Vet Feels At Home. Richmond Times-Dispatch, July 27.

Hoffman, Roy F. 2004. "Kerry, War Hero" Is a Myth. Richmond Times-Dispatch, September 19.

Lewis, Bob. 2004. Kerry, Bush Make Hard Sells For Virginia's Vets' Votes. Associated Press State and Local Wire, September 20.

Marshall, Will. 2004. Heartland Strategy. Blueprint: The New Democrat Magazine, December 13.

McGlennon, John. 2002. Virginia: The Parties Agree It's Out of Play. In The 2000 Presidential Election in the South: Partisanship and Southern Party Systems in the 21st Century, eds. Robert P. Steed and Laurence W. Moreland. Westport, CT: Praeger.

Mercer, Marsha. 2004. Kerry Holiday Visit to Virginia Begins Parade of Speculation. Richmond Times-Dispatch, June 6.

Polsby, Nelson, and Aaron Wildavsky. 2004, 11th ed. Presidential Elections: Strategies and Structures of American Politics. Lanham, MD: Rowman and Littlefield.

Sabato, Larry. 2001. 2001 Gubernatorial Election in Virginia: The Return of Two-Party Competition. University of Virginia Center for Governmental Studies. 
Schapiro, Jeff. 2004. Southern Sweep: Kerry Wins Virginia, Tennessee; Clark Drops Out; Virginia Reprises Role of 2000 in Sealing Kerry's Nomination. Richmond Times-Dispatch, February 11.

Sluss, Michael. 2004. Kerry Campaign Workers Pulled From Virginia. Roanoke Times \& World News, October 5.

Stallsmith, Pamela. 2004. Parties Use Net to Rally Support. Richmond Times-Dispatch, September 6 .

State Board of Elections, Commonwealth of Virginia. 2005a. Statewide Results: Democratic Presidential Primary Election February 10 (accessed at http://sbe.vipnet.org/ feb2004/).

State Board of Elections, Commonwealth of Virginia. 2005b. November 2nd General Election Official Results (accessed at http://www.sbe.virginia.gov/web docs/ Election/Results/2004/Nov2004/).

United States Census Bureau. 2004. State Rankings: Persons 25 Years and Older with a Bachelor's Degree or Higher (accessed at http://www.census.gov/statab/ranks/ rank19.html).

Whitley, Tyler. 2004a. Virginia is Not Too Close to Call. Richmond Times-Dispatch, March 4.

Whitley, Tyler. 2004b. Virginia TV Spots for Kerry a New Spin: Republicans Say Efforts to Classify State a Battleground Could Backfire. Richmond Times-Dispatch, May 29.

Whitley, Tyler. 2004c. Clark First Democrat to Air TV Ad in Virginia. Richmond TimesDispatch, January 7.

Whitley, Tyler. 2004d. Kerry TV Ad in VA Stresses His Service. Richmond Times-Dispatch, June 3.

Whitley, Tyler. 2004e. Anti-Kerry Group Has Local Ties: Swift Boat Veterans Enlist Aid Of Richmond GOP Operative For Their TV Ad Campaign. Richmond Times-Dispatch, August 19.

Whitley, Tyler. 2004f. Kerry's Ads Will Bypass Virginia. Richmond Times-Dispatch, September 10. 
